\title{
Analysis of Namibian Main Grain Crops Annual Production, Consumption and Trade-Maize and Pearl Millet
}

\author{
Theresia Kaulinawa Shifiona ${ }^{1}$, Wang Dongyang ${ }^{2} \&$ Hu Zhiguan ${ }^{2}$ \\ ${ }^{1}$ Institute of Food Nutrition and Development, Chinese Academy of Agricultural Sciences, Beijing, China \\ ${ }^{2}$ Institute of Agricultural Economics and Development, Chinese Academy of Agricultural Sciences, Beijing, \\ China
}

Correspondence: Wang Dongyang, Institute of Agricultural Economics and Development, Chinese Academy of Agricultural Sciences, Beijing, China. Tel: 86-8210-6151. E-mail: wangdongyang@caas.cn

Received: December 17, 2015 Accepted: January 19, 2016 Online Published: February 15, 2016

doi:10.5539/jas.v8n3p70 URL: http://dx.doi.org/10.5539/jas.v8n3p70

\begin{abstract}
Cereal grains are the most important source of the world's total food and staple food for most developing countries. The main objective of this paper is to analyze the Namibian cereal grains by examining trends in annual output, imports and exports as well as consumption volumes for over the period of fifteen years. Due to a variety number of grains being produced and consumed, the main focus is on maize and pearl millet. Data were collected from the Namibian Agronomic Board and from Food and Agriculture Organization of the United Nation Statistical yearbooks for various years. A combination of descriptive statistics has been applied as the method of analysis of the collected data, providing concise summaries about the observations that have been made. The findings show that the production of both maize and pearl millet has increased over the year reviewed due to relative increase in area harvested and yield. Consumption of pearl millet represents one fifth $(20 \%)$ of the national cereal consumption, while maize represents one third (33\%). On average the per capita consumption of maize is around $44 \mathrm{~kg}$ per year while millet is about $29 \mathrm{~kg}$ per year. The consumption of both maize and pearl millet rose at an average annual rate higher than the production rate, particularly for maize. To cover deficits between consumption and production, imports become a viable option, especially for maize.
\end{abstract}

Keywords: annual output, consumption volume, maize, pearl millet, trade

\section{Introduction}

Grains are commonly known to be the source of staple food all over the world with under-developed and developing countries leading in consumption due to their inexpensive nature or readily available as food (Henry, et al 1996; Abdelrahman, 1998). According to Adamowicz (1988), in the under-developed and developing countries, grains represent over 70 percent of the average per-capita intake. From place to place, grains as staple food may vary, for instance in Southern Africa, maize, wheat, sorghum, and pearl millet are dominant as source of staple food. In the case of Namibia as this paper focuses, maize and pearl millet are the main staple food crops grown in the country under both irrigation and dry condition. Grain production in Namibia represents the foundation for the growth of agricultural income, rural employment, consequently contributing to import substitutes and household food security. Namibia is highly vulnerable to climate change, which manifests itself in floods and droughts (Thomas \& Mpofu, 2013). Therefore, changing in rainfall patterns has the potential of bringing disastrous implications to a country like Namibia in terms of agricultural production. Many crops have been lost during the years of severe flood that resulted in low grain production and food shortages. Given these challenges, rainfall pattern has proved to be the main obstacles for both maize and pearl millet which are required in order to attain food security and economic development in Namibia. Namibia has a low and erratic annual rainfall, Averaging $350 \mathrm{~mm}-700 \mathrm{~mm}$ and the temperature can reach $40{ }^{\circ} \mathrm{C}$ in summer, and thus crop production activities are limited, primarily due to dry condition and poor soil fertility (Louise, 2009). According to Mona et al. (2009) the performance of agricultural production in Namibia fluctuates in response to climatic conditions, thus, food self sufficiency varies from $35 \%$ to $75 \%$ of total demand. The production of both maize and pearl millet in Namibia is only possible in the north and north eastern part of the country where rainfall is sufficient and at few irrigation schemes where permanent water is available. Only $1 \%$ of the country's total surface area is suitable for seasonal and permanent crop production and prospects for expansion of staple crop 
production are limited. Thus, the country is likely to remain dependent on imports of all important cereals to meet domestic consumption needs. According to the study conducted by the United Nation Development Programme in 2008, the country has been experiencing severe drought and flood in recent decades which resulted in cereal output reduction and this periodic fall in cereal output creates cereal deficits which increase cereal imports and prices.

Millet known as the world's most important cereal grain in total production (Eric et al., 2012), is commonly named Mahangu (Pearl Millet (Pennisetum glaucum)) in Namibia. It is a subsistence rain fed cereal crop and the most important staple food grain, of which, over $50 \%$ of the Namibian population depend on, mainly produced by small scale farmers in the Northern Communal Areas for household consumption (Matanyaire, 1996). It is a very advantageous crop among other cereal due to the fact that it can be and is grown in area of low rainfall (300 $\mathrm{mm}-500 \mathrm{~mm}$ ) per year, and very high temperature of above $30^{\circ} \mathrm{C}$ (Andreas, 2013; Ibrahim et al., 2012). Pearl millet is the principal source of food security to the majority of the country's small holders, sown to almost $80 \%$ of cropped area and accounts to $24 \%$ of total calorie intake and approximately $40 \%$ of cereal grain intake by Namibian consumers (Rohrbach et al., 1999). Each year, the majority of the Namibian farmers fail to produce enough grain to meet household consumption requirements due to limited rain and frequent drought reducing average grain production, especially for pearl millet (Matanyaire, 1998). Shortage of quality, locally adapted millet seed leads to low yield, as a result, around 5000 tonnes of pearl millet is imported from India as an addition to the domestic production (Mona et al., 2009). Due to a combination of low yields and fluctuating production that made trade infeasible, pearl millet is very thinly traded in the world market (Basavaraj et al., 2010). In Namibia, pearl millet represent one fifth of the national cereal consumption, with maize and white rice representing one third each. According to Leporrier et al. (2004), Millet consumption is significant in both rural and urban households in terms of both the quantity consumed and the frequency of consumption.

On the other hand, white maize is a largely commercially produced staple food grain crop in Namibia, planted under both irrigation and rain fed conditions, with domestic production of more than $50 \%$ of maize requirements (Mona, 2009) and most of it is imported from South Africa. The demand for maize has increased in Namibia as the production of pearl millet has decreased due to flood and drought that affect the country almost every year and more money is spent on the importation of both maize and pearl millet which could be produced domestically. The impact of increase in yield for both maize and pearl millet cannot be overemphasized as it affects rural household food security, health and income generation. Higher yield have proven in many ways to have increased farmer's income and improve food security. According to Joseph (2011), more than $90 \%$ of the maize in Africa is used for food, with an average per capita consumption of about $50 \mathrm{~kg}$ and 30 percent of world food maize is consumed in Africa, with Sub Saharan Africa consuming the vast majority. Maize has been the largest cereal crop in Ethiopia since the 1990s, according to Food and Agriculture Organization statistics data, and its production has increased from an average of 2.3 million tons in the 1990 s to 3.2 million tons in the early 2000s (Shahidur, 2010). The developing countries account for more than 55 percent of cereal trade, and cereal grains imports in these countries have grown at annual rate above 10 percent. The production of cereals in the developing countries has grown to 2.5 percent in the last decades; higher cereal imports for these countries have been due to economic policies that have discouraged domestic production in some countries either through taxing of agriculture or through macroeconomic policies that have reduced needed agricultural investment and infrastructure (OECD, 1993).

The organization of this paper is as follows: part one is introduction. Part two consists of the methodology application used in this paper. Part three contains data description. Part five, gives the results and discussions as obtain from the analysis of data. Lastly part five consists of closing remarks.

\section{Materials and Methods}

The study relies on secondary data compiled from various published sources. The data set of this paper contains harvested area, yield, annual output, import, and export and consumption volume of both maize and pearl millet. The construction of the above mentioned data collection is based on the following years 1999-2013. The accuracy of the results presented here are directly dependent on the data source and the classifications therein. Data on area, production, yield and consumption were obtained from the Ministry of Agriculture, FAO statistics, World Bank and from scientific journals. Data on import and export are been obtained from the Namibia Agronomic Board as well as from the Namibia Statistic Agency. For all crops, domestic availability (the sum of production and net trade, i.e., production + (export-imports)) has been calculated to serve as a proxy for demand. Simple statistical measures such as average and the compound annual growth rates have been computed to analyze the trends. In order to further analyze the per capita availability of each cereal grain per year has been calculated. The availability of the crops differs from consumption with regard to stock variation from year to 
year.

The descriptive statistics has been over the years applied as the method of analysis in many studied fields. It is widely known for providing concise summaries about the sample and about the observations that have been made. Such summaries may be either quantitative, i.e. summary statistics, or visual, i.e. simple-to-understand graphs. These summaries may either form the basis of the initial description of the data be a part of a more extensive statistical analysis, or they may be sufficient in and of themselves for a particular investigation (Manju et al., 2014).

In the same vein, this paper has adopted this method as the main tool for data analysis. Summaries and graphs as well as tables have been presented for simply describing what is or what the data shows.

\section{Results and Discussion}

Over the period studied which is from 1999-2013, the year 2005/2006 and 2012/2013 cropping season, received a favorable rain that contributed to a record local production of 72,438 tons of white maize, from a total of 15,815 hectares planted under irrigation and rain-fed conditions respectively. The average rain-fed yield was 3.3 ton/ha and irrigation farms yielded an average of approximately 7.6 ton/ha. In spite of this rain, the production of both maize and pearl millet was extremely below average. There was a massive reduction in maize output of $48 \%$ below average and 14\% lower than the 2010/2011 harvesting season. The production for pearl millet decreased with $47 \%$ below average and 41\% lower than the 2010/2011 harvesting season. This occurred as a result of heavy rainfall and flooding in most production areas.

Table 1. Annual growth rates of maize and pearl millet production, consumption, and trade (1999-2013)

\begin{tabular}{|c|c|c|c|c|}
\hline & \multicolumn{2}{|c|}{ Maize (1999-2013) } & \multicolumn{2}{|c|}{ Millet (1999-2013) } \\
\hline & Average growth & Annual growth rate $(\%)$ & Average growth & Annual growth rate $(\%)$ \\
\hline Area Harvested (1000 ha) & 28 & -1.6 & 236 & -0.5 \\
\hline Yield per ha (MT/HA) & 1.6 & 7.4 & 0.2 & -5.0 \\
\hline Production (1000 tonnes) & 46 & 5.8 & 57 & -2.7 \\
\hline Food Consumption (1000 tonnes) & 85 & 1.7 & 56 & 0 \\
\hline Import (1000 tonnes) & 71 & 0.9 & 3 & -6.3 \\
\hline Export (100 tonnes) & 2 & -100 & 0 & 0 \\
\hline
\end{tabular}

During the period 1999-2013 maize yield per hectare has rose to an annual average growth rate of 7.4 percent, although there has been a reduction in area harvested. The production has increased with 5.8 percent, with the consumption annual growth rate of 1.7 percent (Table 1). On the other hand, due to a reduction in both area harvested and yield for pearl millet, the production has declined at an annual growth rate of -2.7 percent. An import of maize has increased at an annual growth rate of 0.9 percent. 


\subsection{Maize Area Harvested, Yield, Production and Consumption Trends}

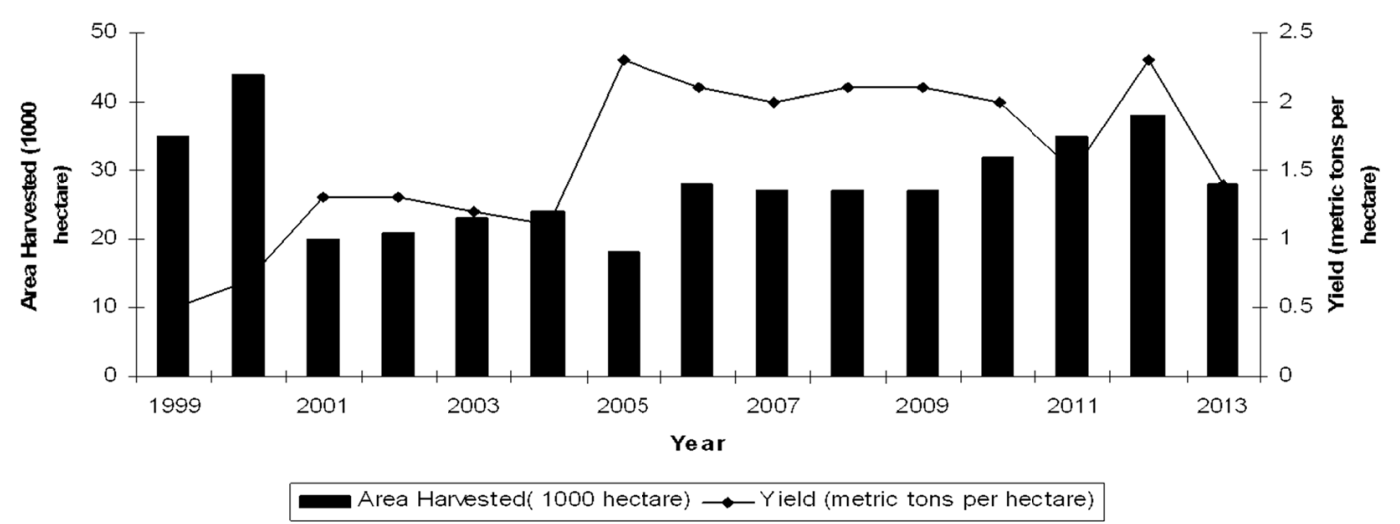

Figure 1. Maize area harvested and yield (1999-2013)

The area under production rose significantly between 2005/2006 cropping season following the drought of 2004 as well as the expansion of irrigation schemes. During that same period, yields doubled from $1.2 \mathrm{MT} / \mathrm{ha}$ to 2.2 $\mathrm{MT} /$ ha and have remained above $2 \mathrm{MT} /$ ha (Figure 1). The contributing factors to this increased yield were attributed by increased irrigation and improved farming practices.

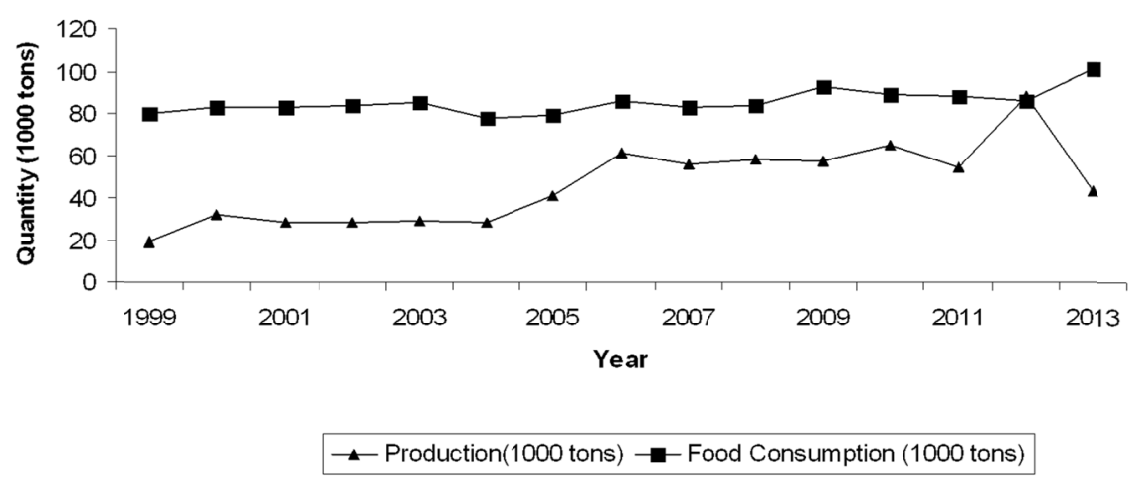

Figure 2. Maize production and food consumption (1999-2013)

There has been an increase in the production of maize between year 1999 and 2009 (Figure 2), which occurred as a result of 300 percent increase in yield, with area harvested decreasing by 24 percent. Between the year 2004 and 2009, domestic demand for maize as food, has trended upward with 16 percent. However, despite this increase in total production from 28,000 MT in year 2001 to 60,000 MT in year 2010, Namibia remains a deficit maize producer, with an average short-fall of $47,000 \mathrm{MT}$ per year. 


\subsection{Pearl Millet Area Harvested, Yield, Production and Consumption Trends}

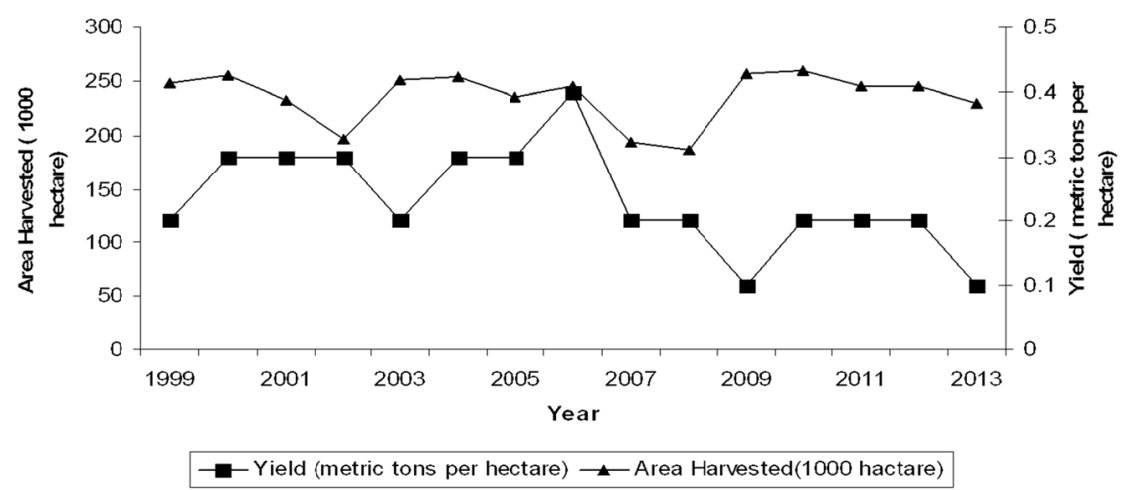

Figure 3. Pearl Millet area harvested and yield (1999-2013)

There has been an inconsistent in the area harvested with pearl millet from 1999 to 2006, with some years having high harvested area while other years having low harvested area. An increase in area harvested in 1999 resulted in an increase in yield from $0.2 \mathrm{MT} / \mathrm{ha}$ to $0.3 \mathrm{MT} / \mathrm{ha}$ in 2002 and another increase in yield from $0.3 \mathrm{MT} / \mathrm{ha}$ from 2004 to $0.4 \mathrm{MT} / \mathrm{ha}$ in 2006. A decrease in area harvested from 2007 to 2009 caused the yield to drop drastically from 0.4 MT/ha to 0.1 MT/ha (Figure 3). Although the area harvested increased from 2009 to 2013, yield per unit area remained low, with a slight increase of up to 0.2 metric tons per hectare.

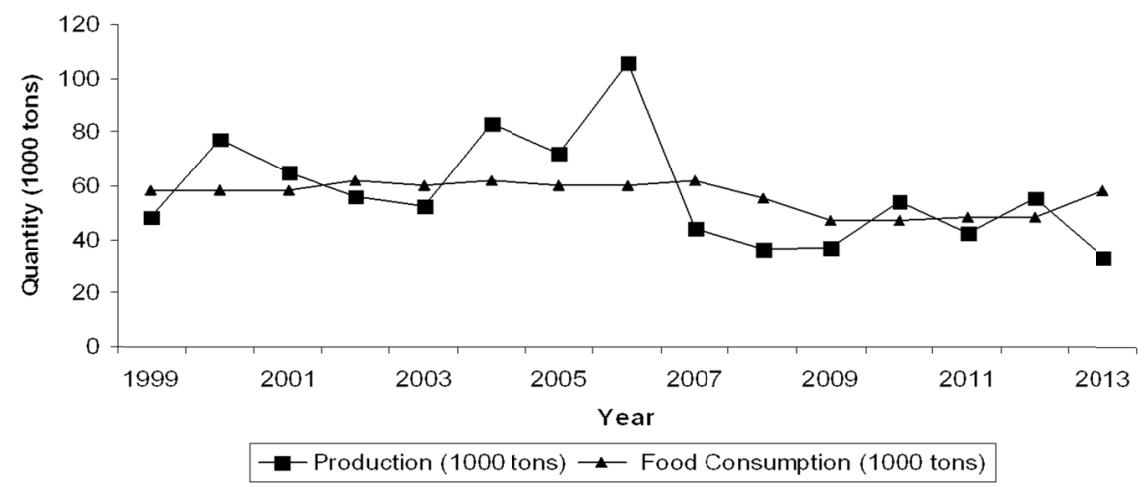

Figure 4. Pearl Millet Production and Consumption (1999-2013)

Pearl millet production increased significantly with 37 percent increase from 52,000 tonnes to 83,000 tonnes during the 2003/2004 cropping season relative to an increase in area harvested. During the year 2007/2008 cropping season, production has dropped drastically from 106,000 tonnes in 2006 to 36,000 tonnes in 2008 (Figure 4). The occurrence of this low production was a result of severe floods in the country leading to farmers producing very little crops. The consumption of pearl millet as food did not change much throughout the studied period from years 1999 to 2007 . The only change experienced was a slight one from 55,000 tonnes in year 2008 to 47,000 tonnes in year 2010 as a result of reduction in production. 


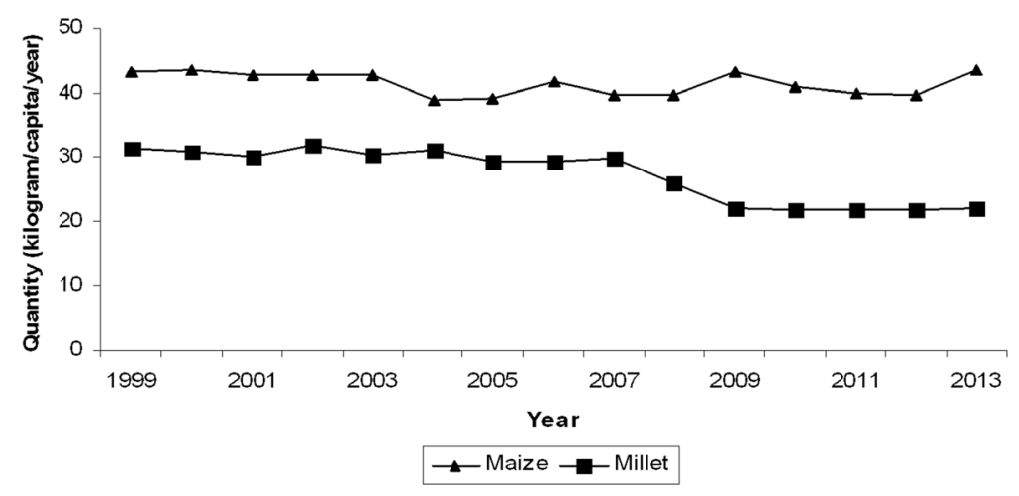

Figure 5. Per Capita Consumption of Maize and Pearl Millet (1999-2013)

The consumption of maize in Namibia is high than that of millet. Pearl Millet represents one fifth $(20 \%)$ of the national cereal consumption, with maize representing one third (33\%), Millet consumption is significant in both rural and urban households in terms of both the quantity consumed and the frequency of consumption. On average the per capita consumption of maize is around $44 \mathrm{~kg}$ per year while millet is about $29 \mathrm{~kg}$ per year. Maize is used as a supplement to Millet especially in rural areas, where maize is mix with millet for different reasons, one being that mixing help to save Millet especially in years of poor harvest, but people in rural areas barely consume maize alone. The practice of consuming maize alone is more common in urban areas where most people consume it without mixing with millet. Between the years 2009 to 2012, the consumption of maize has increased while pearl millet has decreased (Figure 5), this is due to low millet production, thus people relied more on maize which is obtained from irrigation schemes and imports.

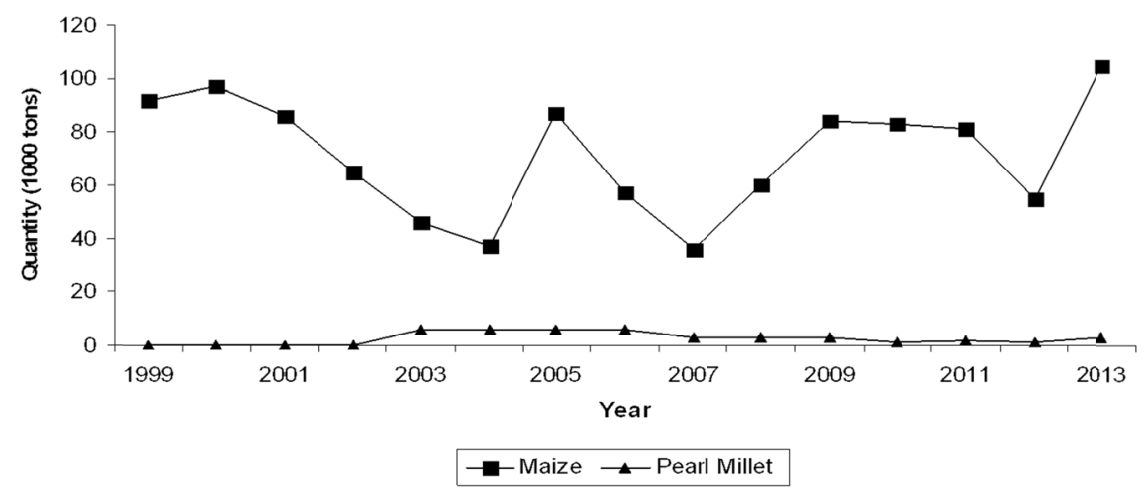

Figure 6. Maize and Pearl Millet Import (1999-2013)

A large quantity of maize has been imported compare to pearl millet, around 97,000 tonnes of maize was imported in 2000, and there has been a reduction in the imports of up $38 \%$ from 2000 to 2004 which occurred as a result of an increase in domestic production (Figure 6). In previous years, Namibia was not importing pearl millet as the country was able to produce almost all the pearl millet needed to meet domestic consumption. From the year 2003, around 6,000 tonnes of pearl millet have been imported as an addition to domestic production. No export of pearl millet has been reported so far in Namibia, but since year 2001 around 2,000 tonnes of maize has been exported to neighboring countries which has increased to 5,000 tonnes in year 2005 .

\section{Conclusion}

This paper has revealed that the production of both maize and pearl millet in Namibia has a slight increase over the years reviewed. Pearl millet which can be grown in areas of low rainfall shows a significant increase in local production with 37 percent as an increase in area harvested than that of maize which is produced under both rain-fed and irrigation and highly produced on commercial farms under irrigation. 
On the other hand, the local production of maize from both rain fed and irrigation has also shown a considerable increase as a result of increase in yield. Despite this increase in production, Namibia still remains the deficit maize producer and has to import maize from South Africa to cover these deficits in order to meet the required domestic maize demand. In contrast, around 5000 tonnes of pearl millet is imported from India due to a reduction in local production caused by drought and flood that recently been occurring in the country. As these crops are the major staple food in Namibia, with pearl millet representing one fifth (20\%) percent of national cereal consumption and maize representing one third (30\%), their consumption has trended up and more is required to meet the demand. In future a number of studies need to be conducted with depth analysis on the "how part' of improving yield of these main grain crops in order to make a country food secure.

\section{References}

Abdelrahman, A. H. (1998). Trends in Sudanese Cereal Production, Consumption, and Trade. Working Paper 98-WP 198 Center for Agricultural and Rural Development Iowa State University Ames, Iowa 50011-1070. Retrieved from http://www.card.iastate.edu

Adamowicz, M. (1988). Grain production and food security in Arab Countries. Agricultural Economics, 2(1), 39-56. http://dx.doi.org/10.1016/0169-5150(88)90030-8

Andreas J. (2013). Trends of pearl millet (Pennisetum glaucum) yields under climate variability conditions in oshana region. Namibia, University of Greifswald, Germany.

Basavaraj, G., Parthasarathy Rao, P., Bhagavatula, S., \& Ahmed, W. (2010). Availability and utilization of pearl millet in India. Journal of SAT Agricultural Research, 8. International Crops Research Institute for the Semi-Arid Tropics (ICRISAT), Patancheru 502 324, Andhra Pradesh, India.

Eric, O., Ernst, C., Bharat, P. S., Rufina, W., Leopold, M. N., \& David, A. M. (2012). Growth and Grain Yield of Pearl Millet (Pennisetum glaucum) Genotypes at Different Levels of Nitrogen Fertilization in the Southeastern United States. Journal of Agricultural Science, 4(12), 155-163. http://dx.doi.org/10.5539/jas.v4n12p155

Food and Agriculture Organisation Statistics. (2013). The Food and Agricultural Organisation's Statistical Database. Land Use Area Database. Retrieved from http://faostat.fao.org/site/377/DesktopDefault.aspx? PageID=377\#ancor

Food and Agriculture Organization/World Food Programme. (2009). Special report, crop, livestock and food security assessment mission to Namibia. Economic and Social Development Department, Food and Agriculture Organization of the United Nations, World Food Programme, Rome.

Henry, R. J., \& Kettlewell, P. S. (1996). Cereal Grain Quality. London: Chapman \& Hall. International Center for Agricultural Research in the Dry Areas (ICARDA). http://dx.doi.org/10.1007/978-94-009-1513-8

Ibrahim, M., Alastair, O., \& Christin, S. (2012). Cereals consumption pattern in Kenya. International Crops Research Institute for the Semi-Arid Tropics (ICRISAT), Nairobi International Center for Agricultural Research in the Dry Areas (ICARDA).

Joseph, M. A. (2011). Major Cereal Grains Production and Use around the World. Soil \& Crop Science Dept./Nutrition and Food Science Dept., Texas A\&M University, 2474 TAMU, College Station, TX 77843-2474. http://dx.doi.org/10.1021/bk-2011-1089.ch001

Leporrier, S., Leveau, A., Dury, S., \& Bricas, N. (2004). Mahangu urban consumption survey: Final report Montpellier (p. 61). CIRAD-AMIS N de rapport: CIRAD-AMIS N 01-2004.

Louise, H. B. (2009). The economic impact of climate change on commercial agriculture in Namibia (Dissertation, University of York).

Manju, K., \& Bhawana, M. (2014). Data Analysis of Students Marks with Descriptive Statistics. Department of Computer Science, JECRC University, Jaipur, India.

Matanyaire, C. M. (1996). Pearl millet production system(s) in the communal areas of northern Namibia: priority research foci arising from a diagnostic study. In K. Leuschner \& C. S. Manthe (Eds.), Drought-tolerant crops for southern Africa (pp. 43-58). Proceedings of the SADC/ICRISAT Regional Sorghum and Pearl Mille t Workshop, July 25-29, 1994, Gaborone, Botswana.

Matanyaire, C. M. (1998). Evaluating benefits from subsistence pearl millet production in the Northern Communal Areas of Namibia. Agrekon, 37(3), 313-318. http://dx.doi.org/10.1080/03031853.1998.9523511

Mona, F., Jürgen, H., \& Klaus, S. (2009). Agriculture: Future Scenarios for Southern Africa-Country Briefing- 
Namibia. International Institute for Sustainable Development, Trade Knowledge Network, Winnipeg, Manitoba Canada.

Namibian Agronomic Board. (2012). Annual Report 1. April 2011-March 31, 2012, NAB, Windhoek, 25.

Namibian Agronomic Board. (2013). Annual Report 1. April 2012-March 31, 2013, NAB, Windhoek, 26.

Organization for Economic Co-operation and Development (OECD). (1993). World Cereal Trade: What Role for Developing Countries. Paris: OECD.

Rohrbach, D. D., Lechner, W. R., Ipinge, S. A., \& Monyo, E. S. (1999). Impact from Investment s in Crop Breeding: The Case of Okashana 1 in Namibia. International Crops Research Institute for the Semi-Arid Tropics Patancheru 502 324, Andhra Pradesh, India.

Shahidur, R. (2010). Staple Food Prices in Ethiopia. International Food Policy Research Institute, Addis Ababa, Ethiopia.

Thomas, B., \& Mpofu, I. D. T. (2013). Competitive environment of the staple food distribution system in Namibia: An assessment of the pearl millet (Pennisetum glaucum) industry. Agricultural Science Research Journals, 3(4), 121-129.

\section{Copyrights}

Copyright for this article is retained by the author(s), with first publication rights granted to the journal.

This is an open-access article distributed under the terms and conditions of the Creative Commons Attribution license (http://creativecommons.org/licenses/by/3.0/). 